\title{
Pembrolizumab-Associated $\mathrm{CD}^{+}$Vasculitic Mononeuritis Multiplex in a Patient With Mesothelioma
}

Michaela C. Baldauf, MD, Monika Kapauer, MD, Markus Joerger, MD, Lukas Flatz, MD, Regulo Rodriguez, MD, Stephan Frank, MD, Ansgar Felbecker, MD, Susanne Hartmann-Fussenegger, MD, and

Thomas Hundsberger, MD

Neurol Neuroimmunol Neuroinflamm 2021;8:e993. doi:10.1212/NXI.0000000000000993

Immune checkpoint inhibitor (ICI) therapy has revolutionized cancer treatment and achieves unexpectedly durable tumor remission. However, therapeutic efficacy comes along at the cost of a wide spectrum of immune-related adverse events (irAEs). Immune checkpoints, such as the programmed cell death 1 (PD-1) receptor, PD-1 ligand (PD-L1), and cytotoxic T-lymphocyte antigen 4 (CTLA$4),{ }^{1,2}$ inhibit T-cell activation and are used by tumor cells to escape the immune surveillance. ${ }^{3}$

Physiologically, immune checkpoints are important for maintaining self-tolerance during $\mathrm{T}$ and B-cell maturation. Thus, their inhibition can trigger de novo or preexisting autoimmune and paraneoplastic disorders. ${ }^{2,3}$ The most common ICI-associated irAEs involve the skin, the gut, and the endocrine organs. ${ }^{1}$ Neurologic side effects and ICI-associated vasculitis are rare, ${ }^{3}$ the latter affecting mostly large and medium vessels. ${ }^{2}$ ICI-associated vasculitic peripheral neuropathy (VPN) and ICI-associatedperinuclear antineutrophil cytoplasmatic antibody (p-ANCA)-positive mononeuritis multiplex ${ }^{4}$ have only been reported once, but without histologic verification. We report an ICI-associated, ANCA-negative mononeuritis multiplex diagnosed by neuromuscular ultrasound and histology.

\section{Case Description}

A 61-year-old woman suffering from a pleural mesothelioma (cT3cN0cM0) was initially treated with carboplatin/pemetrexed followed by maintenance therapy with the anti-PD-1 inhibitor pembrolizumab (timeline shown in figure, A). After 1 year, pembrolizumab was ceased because of suspected but not confirmed ICI-related colitis. After first progression (rib metastasis), pembrolizumab was readministered (3-weekly, 15 cycles) until multiple cutaneous petechiae developed. A skin biopsy demonstrated perivascular lymphocyte infiltrates, suggesting a latestage small vessel vasculitis (not shown). Suspecting a pembrolizumab-associated cutaneous irAE, treatment was stopped. After 2 weeks, she presented with a bilateral foot drop syndrome and paresis in the distribution of the right ulnar nerve. Clinical examination additionally revealed concomitant hypoesthesia/allodynia of the feet, the right hand, and the left thumb.

Motor nerve conduction studies (NCS) demonstrated severe axonal damage (reduced amplitudes, preserved distal latencies, and velocities) in the right median and ulnar nerves as well as both peroneal and tibial nerves. Sensory NCS of the sural and peroneal superficial nerves were absent, and axonal sensory impairment of the right ulnar and the radial superficial nerve was also shown (reduced amplitudes and preserved velocities). EMG (of the right dorsal interosseous muscle and right tibial anterior muscle) demonstrated acute axonal damage. Nerve ultrasound revealed multifocal fascicular nerve swelling (in both sural and ulnar nerves), raising suspicion of a vasculitic neuropathy (figure,
Correspondence

Dr. Hundsberger

thomas.hundsberger@kssg.ch

From the Department of Neurology (M.C.B., M.K., A.F., S.H.-F.); Department of Hematology and Oncology (M.J.); Department of Dermatology (L.F.); Department of Pathology (R.R.), Cantonal Hospital, St. Gallen; Department of Pathology (S.F.), University Hospital, Basel; and Department of Neurology and Department of Hematology and Oncology (T.H.), Cantonal Hospital St. Gallen, Switzerland. 

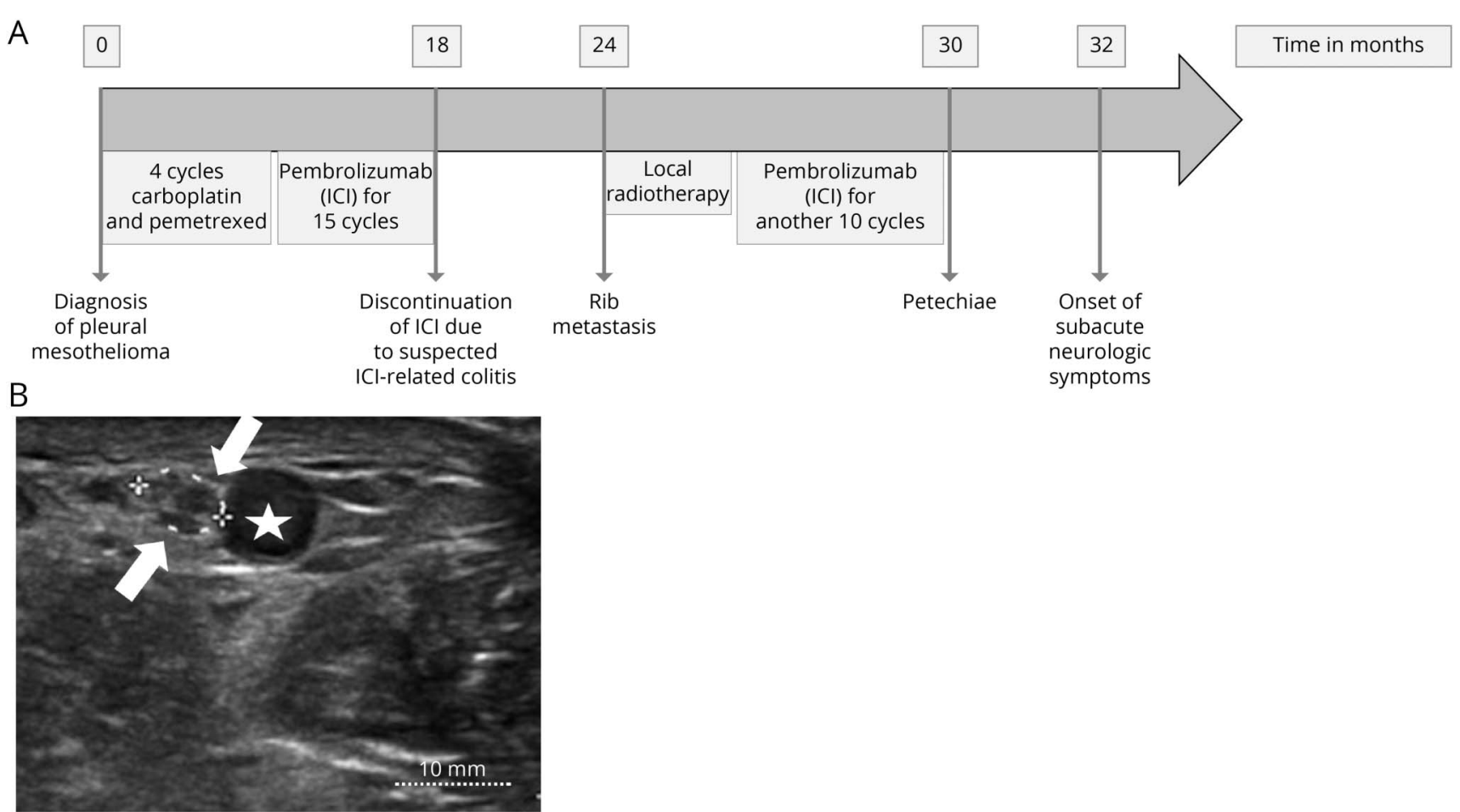

C

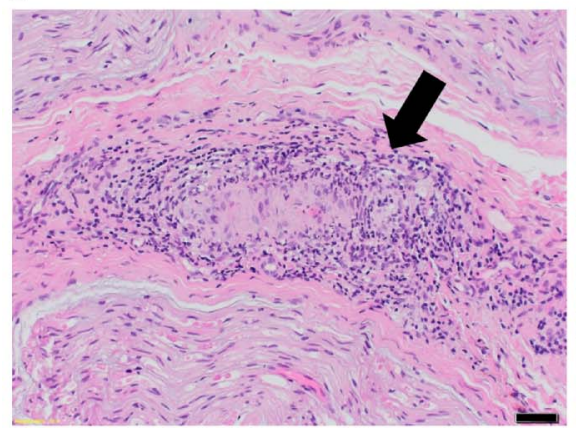

E

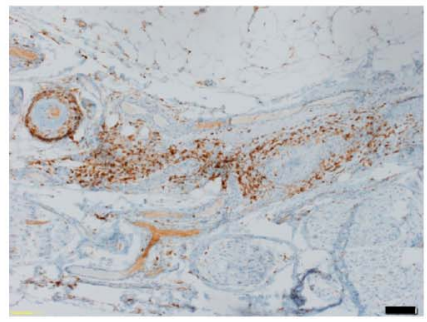

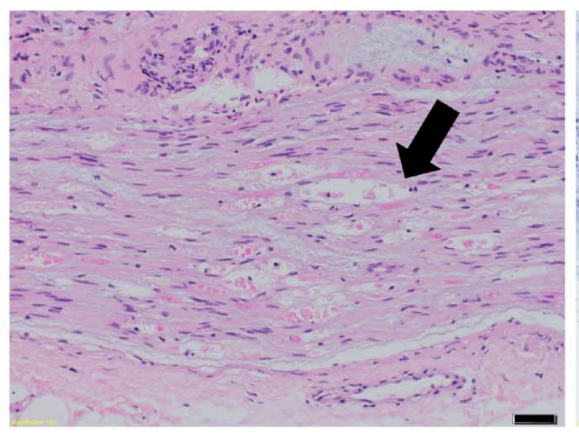

CD8

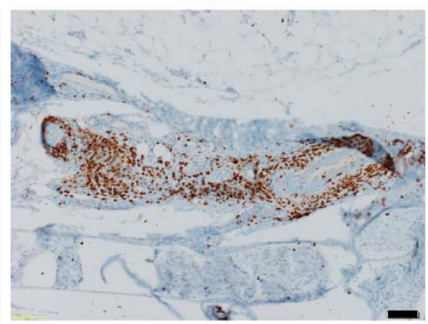

CD20

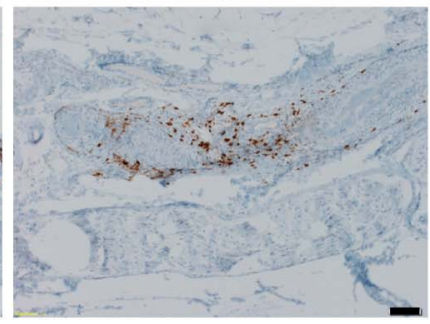

D

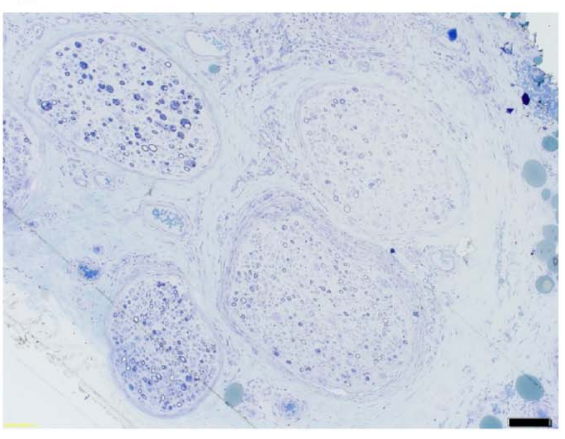

CD68

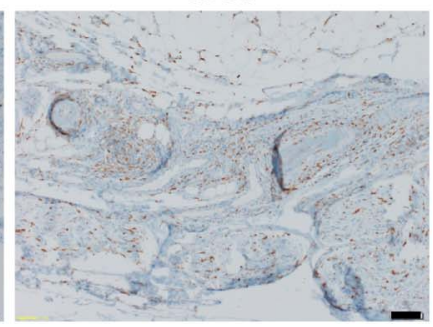

(A) Time course of the patient's history in months. (B) High-resolution nerve ultrasound (18 MHz, Philips Epiq Q5) of the right sural nerve showing fascicular swelling (arrows) and nerve enlargement (dotted circle, cross-sectional area $5 \mathrm{~mm}^{2}$, norm $<2 \mathrm{~mm}^{2}$ ), vein (star). (C) Sural nerve biopsy revealed a small vessel vasculitis with fibroid necrotic changes (arrow) of the vessel wall and myelin sheath disintegration (arrow), hematoxylin and eosin staining. Scale bar; 50 mm. (D) Toluidine blue-stained semi-thin cross-sections of the epon-embedded nerve show signs of axonal degeneration and an inhomogeneous loss of nerve fibers among various nerve fascicles, the latter being a typical finding in vasculitic neuritis. Scale bar; $100 \mu$ m. (E) Immunohistochemistry (brown) for lymphocyte markers CD4, CD8, and CD20; CD68 (macrophages). Scale bar; $100 \mu \mathrm{m}$.

B). The laboratory, CSF, and urine analyses were normal. The clinical phenotype, electrophysiology, and neurosonographic findings were suggestive of a nonsystemic vasculitic mononeuritis multiplex (NSVM) in which an accompanying chemotherapyinduced polyneuropathy may have contributed to the sensory impairment.
High-dose methylprednisolone with subsequent oral tapering was initiated, and an ultrasound-guided biopsy of the sural nerve was performed. Histology confirmed small vessel vasculitis (figure, $\mathrm{C}$ and $\mathrm{D}$ ). The infiltrate showed a predominance of $\mathrm{CD}^{+} \mathrm{T}$ cells over $\mathrm{CD} 4^{+} \mathrm{T}$ and $\mathrm{B}$ lymphocytes (figure, E). 
Because steroids failed to alleviate symptoms, immunosuppression was escalated with IV cyclophosphamide (6 cycles, every 4 weeks). However, severe allodynia persisted, and treatment with pregabaline, amitriptylin, and methadone showed only moderate efficacy.

\section{Discussion}

We are describing a case of histologically proven pembrolizumabassociated sensorimotor NSVM, occurring in a patient with malignant mesothelioma. The clinical hallmark was a painful mononeuritis multiplex preceded by a cutaneous vasculitis. Normal laboratory results (autoantibodies, CSF, and urine) without involvement of visceral organs made a systemic vasculitis with neurologic manifestation unlikely. Chemotherapy-induced polyneuropathy caused by platinum compounds is not inflammatory and mostly sensory because of dorsal root ganglion impairment, which may have contributed to the sensory deficit. A paraneoplastic origin was also unlikely due to the late onset of the neurologic symptoms in the absence of tumor progression, the concomitant irAE to the skin, and the general low incidence of paraneoplastic neurologic symptoms in malignant mesothelioma.

The characteristic composition of immune cell infiltrates in vasculitis is controversially discussed. No data exist so far on ICI-related vasculitis. In giant cell arteritis, inflammation consists mainly of $\mathrm{CD}^{+}$helper $\mathrm{T}$ cells. ${ }^{5} \mathrm{By}$ contrast, $\mathrm{CD}^{+}$cytotoxic $\mathrm{T}$ cells dominate in systemic vasculitis and in NSVM. ${ }^{6}$ In our case, the $\mathrm{CD} 8^{+} \mathrm{T}$ cells dominated the immune infiltrate, which was also reported in ICI-related myositis and myocarditis. ${ }^{7}$

Because of the rarity of the reported case, a comparison with the literature is not feasible, but some aspects might be noteworthy. irAEs often occur after 6-12 weeks of ICI treatment ${ }^{3}$; however, the interval varies with the immune checkpoint target, among other factors. The knowledge about side effects after reexposure to ICIs is very limited. In our case, irAEs evolved over $\sim 30$ weeks after reexposure, which is particularly long. Whether the preceding neurotoxic chemotherapy might have been a trigger for this neurologic irAE remains speculative. ${ }^{3}$

Optimal treatment in ICI-associated NSVM remains to be defined. ICI-associated Guillain-Barré-like syndrome (GBS) resembles the phenotype of classical cases, but steroids are the mainstay of treatment, in contrast to classical GBS. We also treated the patient with high-dose steroids and escalated with cyclophosphamide, which was reasonable according to the irAE treatment guidelines and treatment of NSVM. Careful evaluation and reporting of rare side effects broaden the knowledge and understanding of the complex immune network and the pathogenesis of neurologic ICI-related side effects.

\section{Study Funding}

The authors report no targeted funding.

\section{Disclosure}

The authors report no relevant disclosures. Go to Neurology. org/NN for full disclosures.

\section{Publication History}

Received by Neurology: Neuroimmunology \& Neuroinflammation November 25, 2020. Accepted in final form February 22, 2021.

\begin{tabular}{|c|c|c|}
\hline Name & Location & Contribution \\
\hline $\begin{array}{l}\text { Michaela C. } \\
\text { Baldauf, MD }\end{array}$ & $\begin{array}{l}\text { Department of Neurology, } \\
\text { Cantonal Hospital, St. } \\
\text { Gallen, Switzerland }\end{array}$ & $\begin{array}{l}\text { Neurologic treatment of } \\
\text { patient, wrote article } \\
\text { and created figure }\end{array}$ \\
\hline $\begin{array}{l}\text { Monika } \\
\text { Kapauer, MD }\end{array}$ & $\begin{array}{l}\text { Department of Neurology, } \\
\text { Cantonal Hospital, St. } \\
\text { Gallen, Switzerland }\end{array}$ & $\begin{array}{l}\text { Neurologic treatment of } \\
\text { patient, nerve } \\
\text { ultrasound }\end{array}$ \\
\hline $\begin{array}{l}\text { Markus } \\
\text { Joerger, MD }\end{array}$ & $\begin{array}{l}\text { Department of Hematology } \\
\text { and Medical Oncology, } \\
\text { Cantonal Hospital, St. } \\
\text { Gallen, Switzerland }\end{array}$ & $\begin{array}{l}\text { Oncologic treatment of } \\
\text { patient }\end{array}$ \\
\hline $\begin{array}{l}\text { Lukas Flatz, } \\
\text { MD }\end{array}$ & $\begin{array}{l}\text { Department of } \\
\text { Dermatology, Cantonal } \\
\text { Hospital, St. Gallen, } \\
\text { Switzerland }\end{array}$ & $\begin{array}{l}\text { Dermatologic treatment } \\
\text { of patient regarding skin } \\
\text { vasculitis }\end{array}$ \\
\hline $\begin{array}{l}\text { Regulo } \\
\text { Rodriguez, } \\
\text { MD }\end{array}$ & $\begin{array}{l}\text { Department of Pathology, } \\
\text { Cantonal Hospital, St. } \\
\text { Gallen, Switzerland }\end{array}$ & $\begin{array}{l}\text { Histopathologic analysis } \\
\text { of skin biopsy }\end{array}$ \\
\hline $\begin{array}{l}\text { Stephan } \\
\text { Frank, MD }\end{array}$ & $\begin{array}{l}\text { Department of Pathology, } \\
\text { University Hospital, Basel, } \\
\text { Switzerland }\end{array}$ & $\begin{array}{l}\text { Histopathologic analysis } \\
\text { of nerve biopsy }\end{array}$ \\
\hline $\begin{array}{l}\text { Ansgar } \\
\text { Felbecker, MD }\end{array}$ & $\begin{array}{l}\text { Department of Neurology, } \\
\text { Cantonal Hospital, St. } \\
\text { Gallen, Switzerland }\end{array}$ & Nerve ultrasound \\
\hline $\begin{array}{l}\text { Susanne } \\
\text { Hartmann- } \\
\text { Fussenegger, } \\
\text { MD }\end{array}$ & $\begin{array}{l}\text { Department of Neurology, } \\
\text { Cantonal Hospital, St. } \\
\text { Gallen, Switzerland }\end{array}$ & $\begin{array}{l}\text { Patient treatment, pain } \\
\text { management }\end{array}$ \\
\hline $\begin{array}{l}\text { Thomas } \\
\text { Hundsberger, } \\
\text { MD }\end{array}$ & $\begin{array}{l}\text { Department of Neurology } \\
\text { and Department of } \\
\text { Hematology and Oncology, } \\
\text { Cantonal Hospital, St. } \\
\text { Gallen, Switzerland }\end{array}$ & $\begin{array}{l}\text { Neurologic and } \\
\text { oncologic patient } \\
\text { treatment, wrote article }\end{array}$ \\
\hline
\end{tabular}

\section{References}

1. Heinzerling L, de Toni E, Schett G, Hundorfean G, Zimmer L. Checkpoint-Inhibitoren. Deutsches Arzteblatt International Deutscher Arzte-Verlag GmbH; 2019:119-126.

2. Daxini A, Cronin K, Sreih AG. Vasculitis Associated with immune checkpoint inhibitors-A systematic review. Clinical Rheumatology Springer London; 2018:2579-2584.

3. Astaras C, de Micheli R, Moura B, Hundsberger T, Hottinger AF. Neurological adverse events associated with immune checkpoint inhibitors: diagnosis and management. Curr Neurol Neurosci Rep. 2018:18:3.

4. Dubey D, David WS, Amato AA, et al. Varied phenotypes and management of immune checkpoint inhibitor-associated neuropathies. Neurology. 2019;93:e1093-e1103.

5. Watanabe R, Zhang H, Berry G, Goronzy JJ, Weyand CM. Immune checkpoint dysfunction in large and medium vessel vasculitis. Am J Physiol Heart Circ Physiol. 2017;12:H1052-H1059.

6. Kobayashi M, Ogawa E, Okuyama R, Kanno H. In vasculitis of small muscular arteries, activation of vessel-infiltrating CD8 $\mathrm{T}$ cells seems to be antigen-independent. Virchows Archiv. 2018;472:271-279.

7. Touat M, Maisonobe T, Knauss S, et al. Immune checkpoint inhibitor-related myositis and myocarditis in patients with cancer. Neurology. 2018;91: e985-e994. 


\title{
Neurology \\ Neuroimmunology \& Neuroinflammation
}

\author{
Pembrolizumab-Associated $\mathrm{CD8}^{+}$Vasculitic Mononeuritis Multiplex in a Patient With \\ Mesothelioma \\ Michaela C. Baldauf, Monika Kapauer, Markus Joerger, et al. \\ Neurol Neuroimmunol Neuroinflamm 2021;8; \\ DOI 10.1212/NXI.0000000000000993
}

This information is current as of April 6, 2021

\section{Updated Information \& \\ Services}

References

Subspecialty Collections

Permissions \& Licensing

Reprints including high resolution figures, can be found at:

http://nn.neurology.org/content/8/4/e993.full.html

This article cites 5 articles, 0 of which you can access for free at: http://nn.neurology.org/content/8/4/e993.full.html\#\#ref-list-1

This article, along with others on similar topics, appears in the following collection(s):

All Oncology

http://nn.neurology.org//cgi/collection/all_oncology

Peripheral neuropathy

http://nn.neurology.org//cgi/collection/peripheral_neuropathy

Ultrasound

http://nn.neurology.org//cgi/collection/ultrasound

Vasculitis

http://nn.neurology.org//cgi/collection/vasculitis

Information about reproducing this article in parts (figures,tables) or in its entirety can be found online at:

http://nn.neurology.org/misc/about.xhtml\#permissions

Information about ordering reprints can be found online:

http://nn.neurology.org/misc/addir.xhtml\#reprintsus

Neurol Neuroimmunol Neuroinflamm is an official journal of the American Academy of Neurology.

Published since April 2014, it is an open-access, online-only, continuous publication journal. Copyright

Copyright $\odot 2021$ The Author(s). Published by Wolters Kluwer Health, Inc. on behalf of the American

Academy of Neurology.. All rights reserved. Online ISSN: 2332-7812.

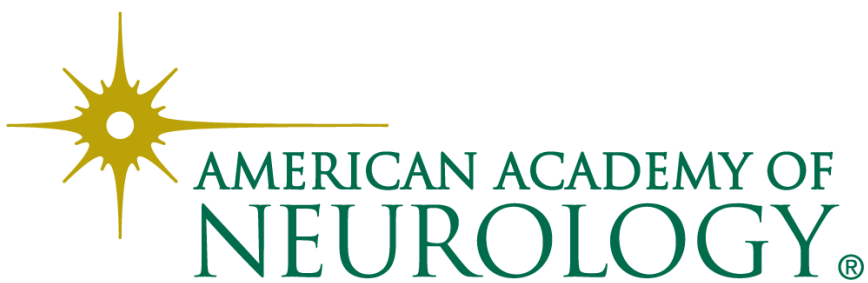

